\title{
SYSTEMATIC LITERATURE RESEARCH ON DISABILITY- RELATED PUBLICATIONS IN HUNGARY FROM 1959 TO THE PRESENT
}

\author{
Beáta Bihariné Kalászdi \\ PhD student, University of Miskolc, Institute of Marketing and Tourism \\ 3515 Miskolc, Miskolc-Egyetemváros, e-mail: biharine.beata@uni-miskolc.hu
}

\begin{abstract}
There are many social problems in every human community, some of which are more prominent and others less prominent in public consciousness. One indicator of this is the number of scientific publications. This research aims to analyze the subject of disability through systematic literature research by examining studies and articles published on the theme, to cover the main publishing trends on disability. The author also aims to find a link between her own research topic - social inclusion of people with disabilities in the light of social marketing models - and already published scientific literature.
\end{abstract}

Keywords: disability, social inclusion, economics publishing trends

\section{Introduction}

Nowadays, many social problems may be the subject of investigation. In my research topic I want to examine and analyze the social inclusion of people with disabilities in the light of social marketing models. This area is of great relevance as a significant part of the population is affected both in the European Union and in Hungary. Besides that it is an important fact that disability can occur in the lives of those who have spent a healthy early stage of their lives - because of accident, illness or old age.

According to the European Health and Social Integration Survey (EHSIS), in 2012 there were 70 million people with disabilities living in the European Union, over the age of 15. This represents $17.6 \%$ of the age group (ec.europa.eu). According to research findings the most affected socio-demographic groups by disability are: women, people over 65 years, people with lower education.

The circumstances of people with disabilities in Hungary was surveyed in the process of the microcensus survey in 2016, and the report was published by the Hungarian Central Statistical Office in 2018 (Micro-census, 2016). Based on this, more than 400,000 people in Hungary live with some form of disability.

As it can be seen from the statistics above, the topic has many direct stakeholders, not to mention other stakeholders (for example family members, educational, health care institutions, etc.)

The importance of our topic is also illustrated by the significant amount of published scientific literature on disability. The purpose of this research is to study the articles published on the subject and to determine what the main aspects are from which researchers approach this multidisciplinary topic.

\section{Research questions and methodology}

The phenomenon of disability has existed since the beginning of mankind, but the attitude of the majority society has changed a great deal over time. While for many centuries the main attitude was 
rejecting the problem, isolating the disabled people and discriminating in every way possible, nowadays we are experiencing positive changes. Society is becoming more and more accepting towards ,different” groups of people from several perspectives, which hopefully will make a positive change in the life of people with disabilities.

If a social problem or phenomenon is important to the society, it is also shown by the fact that it is emerging and gaining importance in the field of literature, arts and science. That is why I consider it important to systematically analyze and examine the scientific literature on disability in order to see how the number of scientific publications on this subject in Hungary changes over the years. In addition, I would also like to examine from which aspects the publications approach people with disabilities. The problem is complex, affecting many disciplines, so it may be interesting to explore which disciplines are over-represented and under-represented in this area. Furthermore, for my own research topic, social inclusion, it is important to explore publications that examine the situation of people with disabilities from this perspective, or other aspects that may be relevant to social inclusion.

Due to the large volume of scientific literature, I restricted my research to the database of the Hungarian Scientific Works (MTMT), examining the results written in Hungarian. During the investigation, I searched for the term ,disabil” (,fogyaték”), which assumed the widest match, resulting 1662 records. The search was made on May 5th, 2019, so the results reflect the state at that time. After clearing the results and deleting the duplicates, 1641 publications remained in the database. I analyzed the data using Microsoft Excel software, to examine the descriptive statistical characteristics of the publications found.

\section{Results}

I first grouped the 1641 articles by the year of publication. The first result in chronological order was published in 1959, so the research sample shows a wide time interval of 60 years. Typically, as we move backwards in time, we get fewer search results (presumably because the database was created in 2009, and publications from much earlier times were not completely uploaded). Search results of 2019 were left out from the analysis, as only one-third of the year has passed at the time of the research, so the seven publications produced so far would distort the sample.

If we look at the temporal distribution, we see that, as shown in Figure 1, there is a significant increase in the number of publications on the topic during the examined time period.

Although the rate of growth is uneven, there are outstanding values (for example in 2004, in 2009 and in 2014) followed by declines, but in its order of magnitude there is definitely strong growth (1 result in 1959, 25 results in 2000, 83 results in 2018). If we look only at the interval since the introduction of MTMT, apart from the outstanding values of 2009 and 2014, the average number of items in other years is between 80 and 90 .

Of all found items 517 publications were published in a journal. A total of 188 journals published articles on the subject, in varying amounts. I examined which journals had the highest proportion of publications on disability.

Figure 2 presents the journals that published most of these articles during the period under review.

As shown in Figure 2, the journals Special Education Review (81) and the Disability and Society (45) have published exceptionally many articles on the subject. In the „middle field” we find the magazines Opportunity (18), Medical Weekly (14), Rehabilitation (14) and Developmental Pedagogy (10). We find 17 journals that have published more than 5 articles on disability in the period under review. 110 magazines published only 1 article on this subject in the investigated period. 


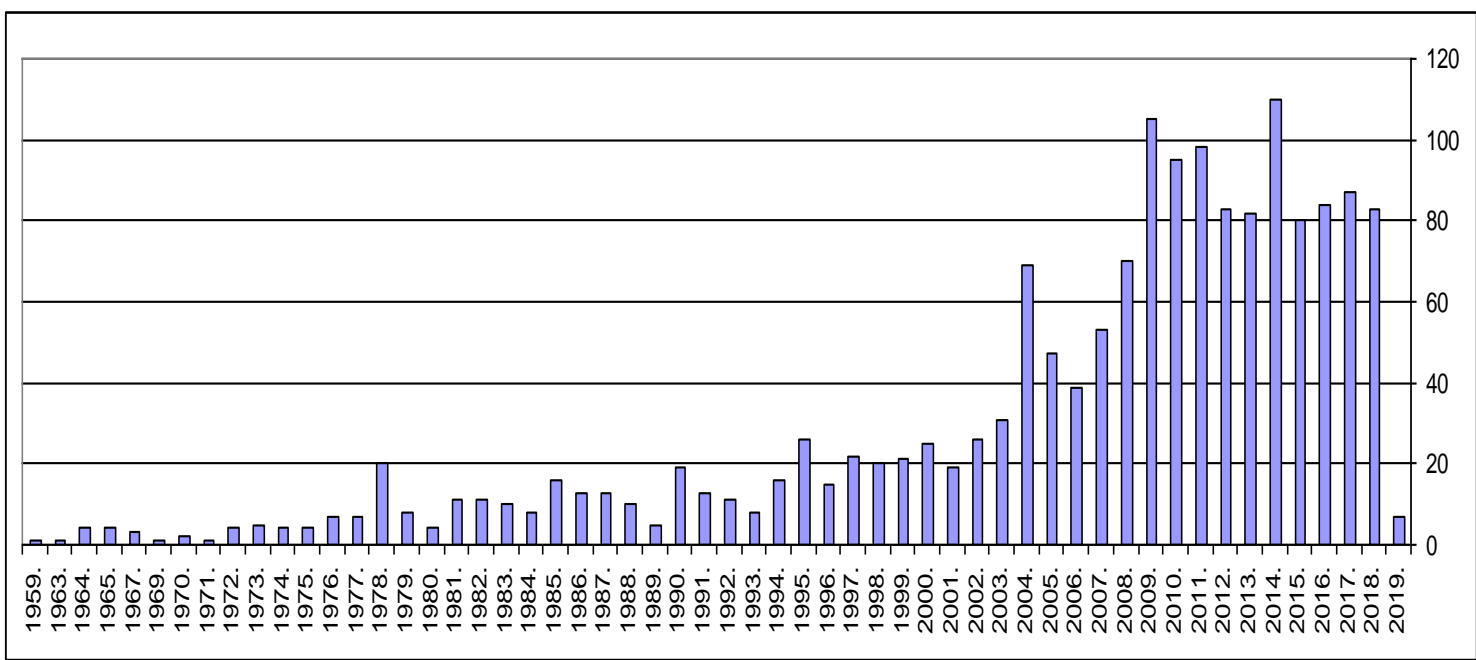

Figure 1. Annual breakdown of publications on disability $(n=1641)$, from 1959 to 2018

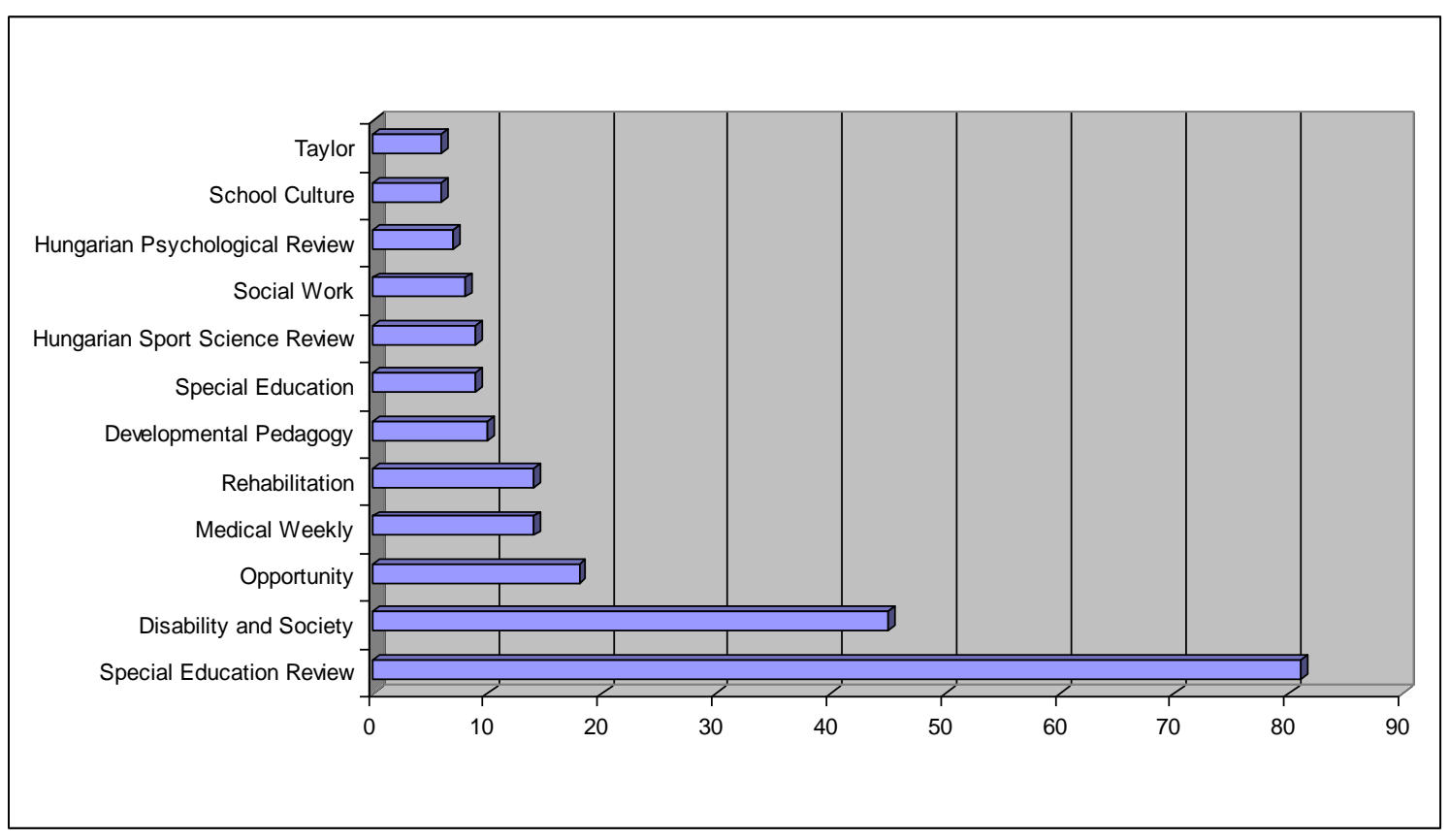

Figure 2. Journals with most publications on disability, from 1959 to 2018

I also examined who the most active authors were in the topic. Dr. Ágnes Lányiné Engelmayer proved to be the most active author in this field, with 62 publications, we can find her articles throughout the whole period (1959-2018). Her main research field is related to intellectual disability (e.g. Lányiné 1964, Lányiné 1985, Lányiné 2002.), but she also deals with other types of disability (e.g. Lányiné 1978a, 1978b, 1978c). Ildikó Laki has 54 publications in the topic, her articles can be found in the MTMT database since 2009. György Könczei published 45 works about disability from 1987 to 2018. 
Eszter Márkus has more than 30 publications on the subject. Figure 3 shows the authors who have more than 10 publications in the topic of disability.

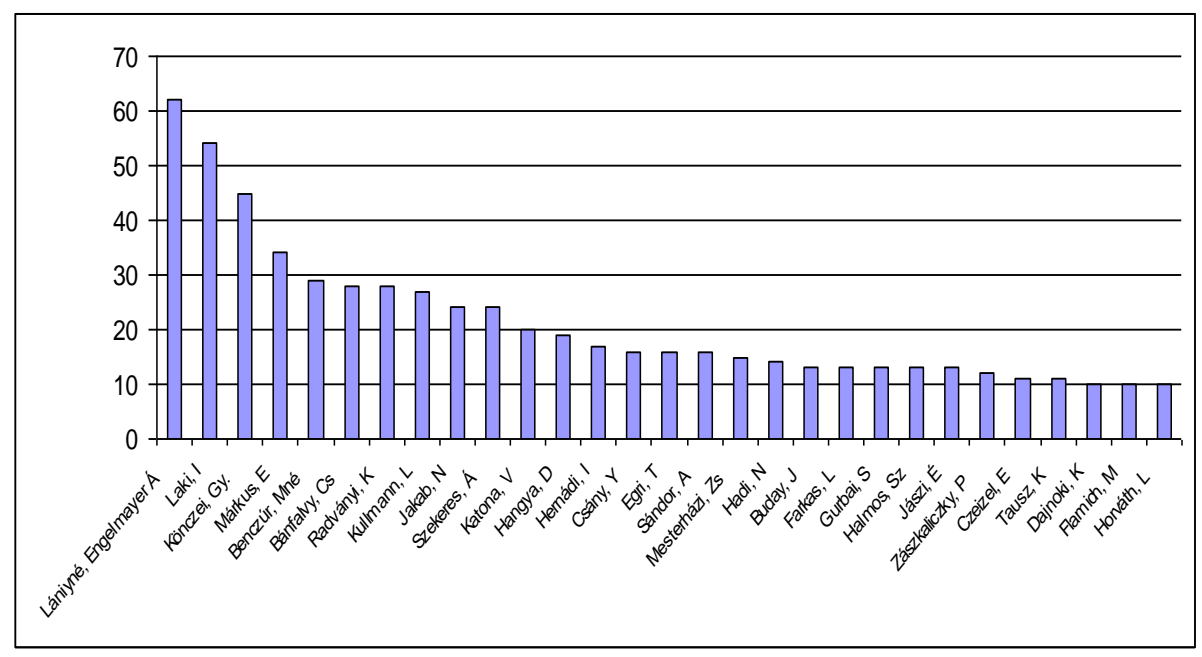

Figure 3. The most active authors in the investigated topic

Disability is a research subject for many scientific disciplines. Based on the titles of the publications received as a result, several areas and categories were outlined, so I categorized the results according to their perspective on disability. I created the following main categories: law, society, economy, health care, pedagogy, sports, institutional care, employment, higher education, special education, arts, tourism, accessibility.

I categorized the publications into the categories above by searching in the titles of the articles with Excel software, applying multiple search terms to each category. For example, I searched for "health”, „rehabil”, „therapy”, „heal”, „medical” to filter articles using the health care approach. Based on the information I received, I was able to categorize the articles into the categories above.

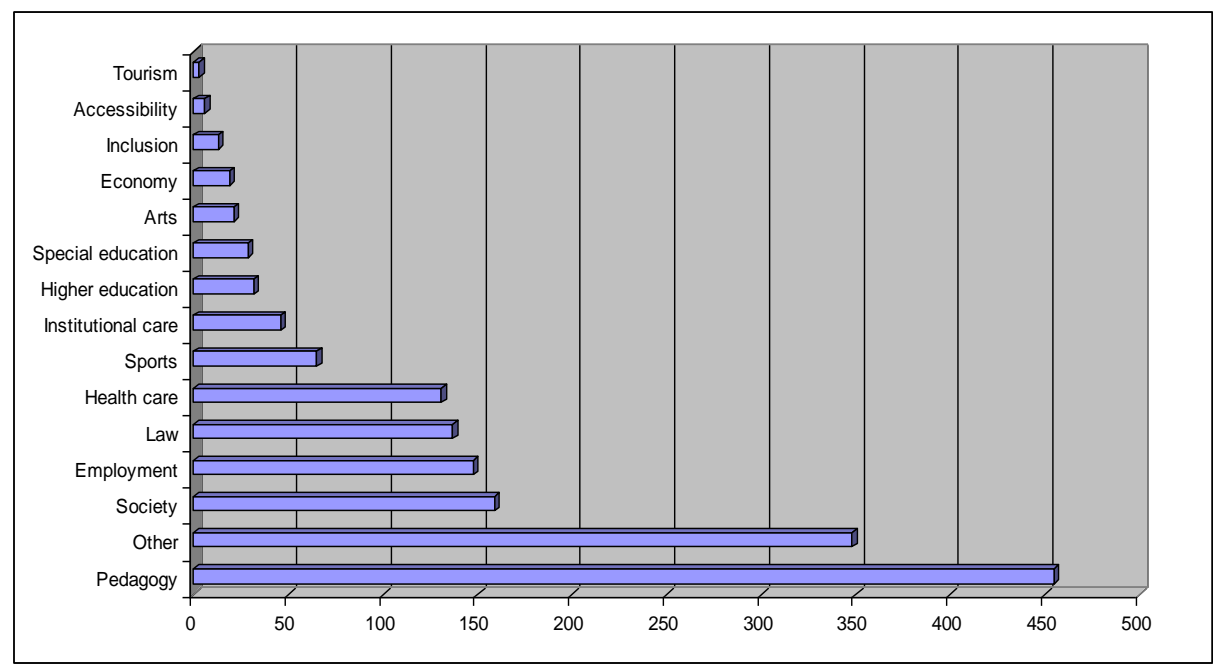

Figure 4. Categorization of publications on disability $(n=1641)$ 
In many cases I received double or triple results. In these cases the articles required „manual” cleaning, so after studying the titles one by one, I had to decide in each case into which category the publication fits. This phase took a lot of time. However, due to the multidisciplinary nature of the topic, certain studies fall into several categories with equal relevance, so they remain in the plural categorization.

There are 348 publications in the „Other" category, which dealt with specific topics or, on the contrary, were too general by their title (e.g. Berzsenyi 2015, Bass 2008, Fehérné Kovács 2009, Nagy 2005, Radványi 2003)

As shown in Figure 4, a significant proportion (455) of the publications deal with the issue of disability from a pedagogical perspective. Publications in this category study the education and school integration of children with disabilities (e.g. Buday 1978, Nagyné 2013, Laki 2011, Némethné 1994) It is well-known that the education has a significant impact on the lives of people with disabilities, since it greatly determines their chances of integration and employment in their adult life.

Publications in the category „Society” play a key role in my research topic. There are also a large number of studies in this category (159). This category also includes the 13 articles found in the subject of „Inclusion”, which together are related to the topic of social inclusion which is also a relevant part of my research interest. I also did a separate search for the term ,social inclusion”, which resulted in a total of 4 results (Bass 2009, Szauer 2009, Tardos 2009, Sáringerné 2014).

According to this it can be stated that the social inclusion of people with disabilities is a less-researched area so far.

Among the publications in the category „Employment”, we also find nearly 150 studies. This theme is also closely linked to the topic of social inclusion, since it is very important for the successfull social integration of a person with a disability to be able to carry out activities that are useful for the society and thus to be financially independent.

The legal approach to disability is also high, with 137 of the publications dealing with this aspect. The legal approach may provide a framework for the subject I am investigating, but it does not show a close relationship with my research subject.

Health care-focused articles also show a similar magnitude (131). These publications mainly deal with the subject of disability from a medical point of view, so they can be used as background information for my further researches.

Sport has been the focus of 65 studies. The view that sport can improve the living conditions and the level of integration of people with disabilities is of great importance in the examined literature (e.g. Bánhidi 2007, Gombás 2016). At the beginning of the research, I did not expect sport to be a significant category, so it gave me new information that this area also has a great impact on the topic I was researching.

46 publications deal with the situation of people with disabilities living in an institution. This number is rather low compared to the approx. 15.000 people with disabilities living in residential institutions according to the Central Statistical Office Yearbook of Social Statistics (2017).

It was a surprising result for me that 32 studies specifically address the issue of disability in the field of higher education. Some of the publications in this category deal with the situation of students with disabilities (e.g. Laki 2015, Karlovitz 2015), while others focus on the attitudes of healthy students and how to sensitize them (e.g. Nagy 2018, Szabó 2018, Mazzag 2005). This category is also important for my research topic, as it also represents a possible direction of narrowing the subject.

Search for special needs education gave 31 results. Although the largest number of studies have been published in the Special Education Review, the number of publications with titles explicitly referring to 
the special education aspect is relatively small. At the same time, we have to take into account that pedagogical and special education results show a strong relationship with each other.

21 publications deal with the emergence of disability in art and the impact of art on people with disabilities, which has also drawn new perspectives (e.g. Tóth-Márhoffer 1990, Kereki 2016).

From a purely economic point of view, only 19 publications deal with disability. At the same time, we must take into account the close relationship between the category „Employment” and the economic aspect.

The number of results on „Accessibility” and „Tourism” was the lowest (accessibility: 6, tourism: 3).

The search for „Marketing” did not match any of the titles, which means that approaching the topic from this aspect represents a novelty.

I also examined the database to see whether the titles of the articles specifically refer to one type of disability and if so, which types are mentioned and how often. $72 \%$ of the 1641 publications examined uses a generic name (people with disabilities, children with disabilities, disability, etc.). 462 publications mention some type of disability in the title. We have to underline the over-representation of using „mentally handicapped” expression in the titles (in $69 \%$ of the articles containing concretisation, which means that in 320 cases we can find this type of disability in the titles). The frequency of the named disability types is shown in Figure 5.

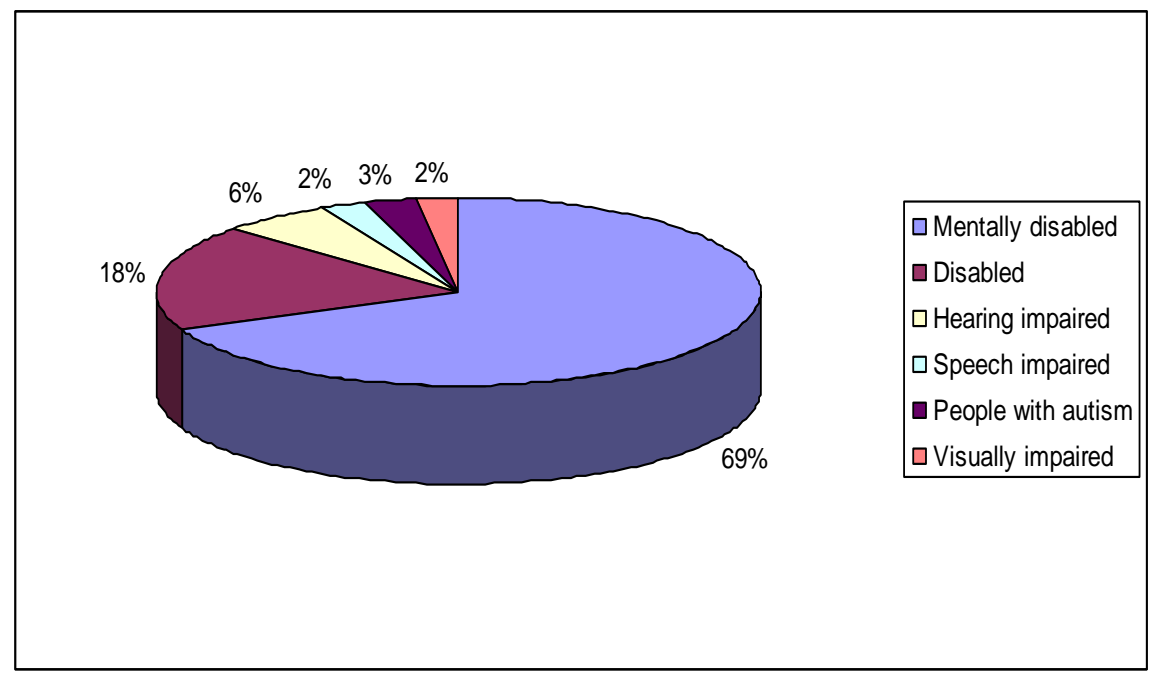

Figure 5. Distribution of publications specifying the type of disability according to the named disability type

\section{Conclusions, further investigations}

The purpose of the research described above was to explore the size and main statistical features of the Hungarian scientific literature on the topic of disability. People with disabilities are an important and large group in our society, so I think it is a relevant research subject to explore the importance of this topic in the scientific literature, since the more important a social problem to the community is, the greater weight the topic has in the field of scientific researches. My aim was, therefore, to examine the direction and extent to which the number of scientific works published in the field of disability has changed over the past decades and which focus the researches have. 
The large number of publications (1641) found during the examined period (1959 - 2018) shows that disability is a relevant, well-researched and published area of the Hungarian scientific literature. Regarding the temporal distribution of the articles published on the topic, I found that there is a clearly increasing tendency, with some outstanding peaks. In the last decade we can find $80-90$ publications in average per year.

Because of the multidisciplinary nature of the topic, I found it important to categorize the publications according to their perspective on disability. After completing the categorization, I found that most publications appeared in the „Pedagogy”, „Society”, „Employment”, „Law”, „Health care” categories. It is an important conclusion from the point of view of my further research that disability literature is still dominated by the traditional approaches of health care, pedagogy, special education, which calls attention to the need of the new approach of social marketing, which is an effective tool both in realising attitude formation, behavior change and establishing the necessary cooperation between the stakeholders of a problem. Based on my research, this approach does not appear in the published scientific literature so far.

I have identified several limitations of the research described. Unfortunately, I did not have access to article abstracts in the MTMT database, which narrowed the search to titles. Due to the large sample size (1641), it was not possible to look up the abstracts one by one from other databases.

Other limitations of the research also indicate further possible directions of the research. The search could be carried out in other databases (for example MATARKA) and the results could be compared, of course deleting the duplicates. It would also be relevant to search for other keywords, such as „,impaired” (,sérült”), which however also yields a very wide (over 1000) results and require significant cleaning of the sample, as many other non-disability-related injury articles also appear in it. It would also be possible to search for specific types of disability (for example „blind”, „visually impaired”, „hearing impaired”, „handicapped”, etc.). Only Hungarian results were included in this research, so an English search in the MTMT database could be done. In addition, there is an opportunity for further expansion if the research is carried out in foreign language databases (for example EBSCO, Researchgate, etc.).

However, these potential further researches are very time consuming and due to the large number of results, can be difficult to manage informatically, therefore a more limited research has been carried out according to current possibilities. The present study also provided useful information to illustrate the importance of the topic in the scientific literature and to identify new thoughts and directions for further research.

\section{References}

[1] Bánhidi, M.: Mozgás és sport a fogyatékos emberek életében, mint lehetőség az esélyegyenlöséghez, 2007.

[2] Bass, L. et al.: Fogyatékos emberek társadalmi befogadása-a szociális ellátórendszer feladatai, lehetôségei - Szociális ellátás, 2009. ISBN:9786155043093

[3] Bass, L.: Amit tudunk és amit nem az értelmi fogyatékos emberek helyzetéröl Magyarországon, 2008.

[4] Berzsenyi, E.: Fogyatékosság és testkép az ókori Közel-Kelet magas kultúráiban, Megjelent: Tudás-Tanulás-Szabadság (2015) pp. 46-47.

[5] Fehérné Kovács: A beszédfogyatékos felnöttek helyzete Magyarországon, 2009. ISBN:9789638789990

[6] Gombás, J. et al.: A testkultúrával összefüggő területek jelentősége a fogyatékos személyek életében Életminőség és sport, 2016. 
[7] https://ec.europa.eu/eurostat/statistics-explained/index.php?title=Disability_statistics__barriers_to_social_integration

[8] Karlovitz, J.: Fogyatékkal élö hallgatók a felsőoktatásban - Jó gyakorlatok, 2015.

[9] Kereki, J.: Frida Kahlo élete, müvészete szenvedése - fogyatékosságának fényében, Fogyatékosság és Társadalom 2060-8292 7 szeptember (2016) pp. 73-84.

[10] Laki, I.: A felsőoktatás hallgatói - a fogyatékossággal élő hallgatók felsőfokú tanulmányai, Megjelent: Fejlődő jogrendszer és gazdasági környezet a változó társadalomban (2015) pp. 340348.

[11] Laki, I.: Fogyatékos fiatalok oktatási integrációja, 2011.

[12] Lányiné Engelmayer, Á.: A serdülőkor problémája értelmi fogyatékosoknál, Megjelent: A fogyatékos gyermekek nevelésének kérdései (1964) pp. 54-61.

[13] Lányiné Engelmayer, Á.: A hallási fogyatékosok intelligenciája, Megjelent: Gyógypedagógiai pszichológia (1978) pp. 137-140.

[14] Lányiné Engelmayer, Á.: A korai gyógypedagógiai segitségnyújtás az értelmi fogyatékosok nevelésében In Gyógypedagógiai Továbbképzés Könyvtára 24., 1985.

[15] Lányiné Engelmayer, Á.: A látási fogyatékosok intelligenciája, Megjelent: Gyógypedagógiai pszichológia (1978) pp. 96-98.

[16] Lányiné Engelmayer, Á.: A mozgásfogyatékosok intelligenciája, Megjelent: Gyógypedagógiai pszichológia (1978) pp. 155-156.

[17] Lányiné Engelmayer, Á.: Intelligencia, IQ, értelmi fogyatékosság. Megjelent: Az intelligencia és az IQ-vita (2002) pp. 111-127. https://doi.org/10.1556/mpszle.57.2002.1.6

[18] Mazzag, É.: A fogyatékosság megitélése a FEEK hallgatói körében. Tudásmenedzsment 15860698 VI. 2. (2005) pp. 100-110.

[19] Micro-census 2016. / 8. (2018) Characteristics of the population with disabilities and handicapped through health reason, Central Statistical Office, Budapest

[20] Nagy, J.: "Intenziv szivterápia" - a fogyatékosság iránti érzékenyités a pedagógushallgatók körében, 2018.

[21] Nagy, K.: Fogyatékos emberek Magyarországon. Szociális Munka 0865-347X 1 (2005) pp. 321.

[22] Nagyné Hegedűs: Enyhén értelmi fogyatékos gyermek az osztályban, 2013.

[23] Némethné Tóth: Értelmi fogyatékosok tanitása összevont osztályban, 1994. ISBN:9636824169

[24] Radványi, K.: A fogyatékosok éve alkalmából, Pomázi Polgár: A Pomázi Önkormányzat Lapja 1587-7604 2003. május

[25] Sáringerné Szilárd: Fogyatékossággal élők sportolási lehetőségei, Megjelent: Társadalmi befogadás a sportban és a sport által (szociális inklúzió) (2014) pp. 93-109.

[26] Szabó, Z. et al.: Sportszakos hallgatók körében végzett attitüd vizsgálat a fogyatékossággal élók sportjával kapcsolatban, 2018.

[27] Szauer, Cs.: Társadalmi, közösségi szintü érzékenyités - a fogyatékos emberek szerepének, helyzetének bemutatása, társadalmi szemléletváltás, az elfogadottság elösegitése a kommunikáció eszközeivel, Megjelent: Fogyatékos emberek társadalmi befogadása - a szociális ellátórendszer feladatai, lehetőségei - Szociális ellátás (2009) pp. 71-77.

[28] Tardos, K.: Társadalmi befogadás és felelösségvállalás a vállalati szférában, Megjelent: Fogyatékosság és a mai magyar társadalom (2009) pp. 35-56.

[29] Tóth-Márhoffer, M.: Az elefántember: Fogyatékosokat bemutató müalkotások elemzése, 1990.

[30] Yearbook of Social Statistics, 2016 (2017) Central Statistical Office, Budapest 